\title{
Predictive Analysis of Hip-hop Dancers' Motivation for Choreographing from Choreography Components (Body-Thinking-Space-Time)
}

\author{
Vivi Angelina and Juneman Abraham \\ Department of Psychology, Faculty of Humanities \\ Bina Nusantara University
}

\begin{abstract}
This study aimed to examine several variables to predict motivation in creating dance choreography, i.e. sense of embodiment, integrative thinking, object and spatial imagery, as well as two types of time perspective (Present Hedonistic and Future). The participants of this study were 34 female Hip-hop dancers and 31 male Hip-hop dancers $\left(n=65, M_{\text {age }}=21.08\right.$ years old, $S D_{\text {age }}=1.674$ years old) in Jakarta, the capital city of Indonesia, recruited via convenience sampling. Data were obtained through psychological scales and were analyzed using a multiple linear regression analysis. Results showedthat (1) the adaptive behavior dimension of motivation could be predicted from the sense of embodiment, object and spatial imagery, and time perspective of future and present hedonistic; (2) the adaptive cognition dimension could be predicted from the object and spatial imagery; (3) the maladaptive behavior dimension could be predicted from the object and spatial imagery and present hedonistic time perspective; and (4) the maladaptive cognition dimension could be predicted from integrative thinking, spatial imagery, and present hedonistic time perspective.
\end{abstract}

Keywords: dance choreography, embodiment, integrative thinking, imagery, time perspective, motivation, art psychology

Penelitian ini bertujuan untuk menelaah sejumlah variabel yang diperkirakan mampu meramalkan motivasi menciptakan koreografi tari, yakni perasaan ketubuhan, berpikir integratif, imajeri objek dan keruangan, serta dua tipe perspektif waktu (kekinian-hedonistik dan masa-depan). Partisipan penelitian ini adalah 34 perempuan dan 31 laki-laki penari Hiphop $\left(n=65, M_{\text {usia }}=21.08\right.$ tahun, $S D_{\text {usia }}=1.674$ tahun) di Jakarta, ibukota Indonesia, yang direkrut melalui teknik penyampelan konvenien. Data diperoleh melalui skala-skala psikologis yang kemudian diolah dengan menggunakan teknik analisis regresi linear berganda. Hasil penelitian menunjukkan (1) aspek perilaku adaptif dari motivasi mampu diramalkan oleh perasaan ketubuhan, imajeri objek dan keruangan, perspektif waktu masadepan dan hedonistic-kekinian; (2) aspek kognitif adaptif mampu diramalkan oleh imajeri objek dan keruangan; (3) aspek perilaku maladaptif mampu diramalkan oleh imajeri objek dan keruangan serta perspektif waktu kekinian-hedonistik; dan (4) aspek kognitif maladaptif mampu diramalkan oleh berpikir integratif, imajeri keruangan, dan perspektif waktu kekinianhedonistik.

Kata kunci: koreografi tari, ketubuhan, berpikir integratif, imajeri, perspektif waktu, motivasi, psikologi seni

Dance is an effective medium to express art and aesthetic values. Hayes (as cited in Setiawati, 2008) stated that the values of aesthetic are inherent and critical in a dance performance, as manifested in the

Correspondence concerning this article should be addressed to Vivi Angelina and Juneman Abraham, Department of Psychology, Faculty of Humanities, Bina Nusantara University, Jl. Kemanggisan Ilir III no. 45, Palmerah, DKI Jakarta 11480. Email: viiangelina@gmail.com; juneman@binus.ac.id unified beauty of a series of dance motions, a variety of body movements, composition, and harmony. As many young people in this modern era lack of the sense of art, dance has become an aspiring and important way to channel the aesthetic need.

Art can be utilized to deal with adversaries of life that can generate destructive effects, such as disputes and conflicts (Sutrisno, 2015). It is not uncommon 
that idea expressions turn out to have adverse effects, such as offending, even assaulting others, and in this case, the expression of art as a neutralizer against negative meaning seems to be less apparent. In this regard, a sense of art comes into play through aesthetic feeling that emerges and functions as a means to signify beauty within oneself (Sutrisno, 2015).

Ever since being exposed, Hip-hop dance has kept evolving until now. Since 2000, Hip-hop dance has been commercialized, and thus, begun to lack its originality and beauty (Roberts, 2012). Owens (2015) argued that the basic identity of Hip-hop dance as the breaking representation begins to deteriorate, and thus, being interfered with industrial interests. The deterioration of Hip-hop choreography in quality nowadays is indicated by the fact that fewer artists maintain the basic identity of Hip-hop dance through creative representation in the choreography.

The choreography of dance requires cognitive process, which is to imagine, to perceive and to form motions (Ashley, 2002). Forgeard and Mecklenburg (2013) stated that (1) cognitive processes interact with motivation in the creative process, and (2) the abstract and global cognitive processing styles enhance the creative thinking. Cognitive process involved in the creation of dance choreography may be analogous to the one involved in a painter's creation, that is "(1) the processes of image generation in an actual artist at work, (2) processes of transcending the artist's previous works, and (3) relationship between creativity and body movement" (Yokochi \& Okada, 2005, p. 242). In those cases, one's cognitive ability, in essence, plays a role in reflecting and dialoguing with his/her own ideas, avoiding "trap" of conformity to previous works, and combining mental and physical activities. All three make a person able to master even manipulate constraints handcuff creativity, and free oneself to be creative.

In the other direction of predictive relationships, motivation to be creative can also increase a person's cognitive abilities, hence the person is compelled to seek knowledge as much as possible and to strive for originality, persistence, and flexibility in its work (Hayes, 1989). However, this present study focuses on the role of cognition in predicting motivation. A case indicating the lack of strong motivation on the basis of cognitive efforts was shown in the plagiarism incident of choreography by the Rumingkang dance choreographer ("Koreografer Rumingkang", 2010). The complexities in dance creation clearly show that one needs sufficient motivation to engage oneself in the whole process until completion. In this regard, plagiarism is a form of low mental investment (Collins, Judge, \& Rickman, 20015; Holt, Fagerheim, \& Durham, 2014; Masic, 2014).

Motivation is the driving force for an individual to accomplish an activity. Similarly, in dance choreography, a dancer needs motivation. According to Martin (2012), motivation is defined as a form of energy and force for a person to learn, work effecttively, and achieve his/her potential by engagement through his/ her behaviors, which should be in harmony with the energy and force. Motivation and engagement are inseparable elements for achievement, in which engagement is the real representation that can be observed from motivation, while motivation is a form of energy that cannot be seen (Martin, 2005).

Based on their definitions, Motivation and Engagement Wheel was developed to show the multidimensional framework, which represents cognition and behaviors typically inherent in motivation (Liem \& Martin, 2012). Liem's and Martin's concept of Motivation and Engagement Wheel is an applicative model of motivation that is holistic and integrative because it is able to capture and summarize coherently and effectively the complexity of elements and dimensions in the existing motivation theories coherently and effectively (Nagabhushan, 2012; Xueyan, 2013). This model is described as circular and it presents in the four dimensions of motivation covering eleven sub-dimensions, namely (1) adaptive cognitive dimensions (embracing values, learning focus, and self-efficacy); (2) adaptive behavioral dimensions (embracing planning, persistence, and task management); (3) maladaptive or impeding cognitiveaffective dimensions (embracing anxiety, failure avoidance, and uncertain control); and (4) maladaptive behavioral dimensions (embracing self-handicapping and disengagement) (Martin, 2007). The theories that are covered by the comprehensive model of motivation, based on the order engirdling the Wheel, are (1) goal theory, self-determination theory, expectancyvalue theory, and self-efficacy; (2) self-regulation theory and choice theory; (3) control and attribution theories, need of achievement theory, self-worth motivation theory, and (4) anxiety, self-handicapping, disengagement, and failure avoidance; and the theories are a synthesis of approaches including cognitive and behavioral orientation, affective strategies used by someone to establish engagement, as well as the differentiation of the strength and direction of the various motivational aspects (Nagabhushan, 2012; Xueyan, 2013). 
As mentioned earlier, motivation has four main components (Martin, 2010), which are High Adaptive Behavior and High Adaptive Cognition, as well as Low Maladaptive Behavior and Low Maladaptive Cognition. In this present study, Adaptive Behavior is shown through a dancer's persistence in creating dance choreography, accomplishing dance choreography, and managing all tasks of the dance choreography. Maladaptive Behavior is seen through his/ her efforts in reducing the chance of success in creating an appropriate choreography, and giving away his/her task completion in doing so. Adaptive Cognition is shown by his/her self-confidence that he/she can create dance choreography, by his/her view that the creation activity is beneficial, and by his/her focus on under-standing and developing skills in the activity. Mal-adaptive Cognition is shown through his/her anxieties and worries with the possibility of failure, his/her reluctance to participation in the creation due avoiding failure, and his/her uncertainties in creating acceptable dance choreography.

There are three basic components in creating dance choreography, which are space, time, and energy (Ambrosio, 2010; Hawkins, 1991). Space refers to the spatial structure which includes the movement repertoire of dancers, in relation to other varied components in the repertoire, such as a specific movement shape in harmony with the surrounding objects (Ambrosio, 2010). With the ability to control his movement repertoire, a dancer needs an appropriate visualizing skill in relation to his body movements, as well as the surrounding medium of the dance. Individuals have different imaginative skills. The image is a mental projection that emerges in her mind when she imagines something. In creating a choreography, a person's feasibility in establishing images of movements will strengthen her stronger motivation in doing so. There are two imagery references used, which are Object Imagery and Spatial Imagery (Blajenkova, Kozhevnikov, \& Motes, 2006). Regarding Object Imagery, one needs to visualize something in a more concrete and colorful way (Blajenkova et al., 2006). This imagery is related to the visual ways a choreographer creates dance with beautiful movements. A person also needs to control his imagination of the movement shapes as well as the corresponding spatial transformation. The controlling feasibility in this regard affects his motivation to create a movement without having difficultties, as normally so with a lower imagination level. Furthermore, Franklin (2012) stated, "A dancer may externally place an image on the surface of her body, in the intimate space surrounding her, in the larger per- sonal space, or on the whole stage, even the entire world" (p. 62) Individuals with the higher skill of Spatial Imagery will be more likely to imagine threedimensional images easier (Blajenkova et al., 2006). In this regard, the skill is utilized, particularly when a dancer makes use of her movement repertoire as part of the basic choreography component, which is space. An aspect of dance performance is the relation between dancers and their audience. Spatial Imagery allows the dancer to identify connections among objects in the context of the performance. Imagery deals with the development of mental ability, such as selfconfidence, dealing or coping with pressure, and motivation (Weinberg, 2008).

The second component of dance choreography is time, as shown in how a dancer or choreographer perceives time and makes use of it as a part of her works (Ambrosio, 2010). The perspective of time is also concerned with the underlying philosophy of the Hiphop dance and its dancers. Some of the keywords of the perspective of time are clearly shown in the Hip-hop history, such as "battles", "new style", and "evolving all time". The history background of Hiphop regarding new style development is related with the time perspective of Present Hedonistic, and the history background of Hip-hop as a battle is shown in the time perspective of Future. Regarding the creation of dance choreography, the two perspectives of time are preferred, so as to describe the achievement of objectives set in the future, which is in this regard the creation of dance choreography.

The third component of dance choreography is energy, which represents the quality of movements of a dancer's performance (Ambrosio, 2010). Energy refers to the dynamics transmitted through a dancer's physical body to generate more fascinating movements (Ambrosio, 2010). Energy is built on the interactions between his body and mind to produce a certain result. Kilteni, Groten, and Slater (2012) stated that individuals could sense something in their body, as they continuously interact with the environment, in which it is a concept called Sense of Embodiment. By signifying his body, a dancer acts in a way that shows his existence as an individual (Brouwer, 1992). A dancer involves her physical body as a whole, and therefore, it would be difficult for her to express herself in the body that she does not belong to. The sensation of locality shows how accurate a person signifies his body. The sensation of agency shows his feeling in moving his body. The sensation of body ownership shows one's feeling in fully controlling her sensations and perceptions of the body. The more a dancer owns, 
controls, and exists in his body, the more likely her motivation in creating the dance choreography increases, as she makes use of his physical body as the channeling medium of energy. The Adaptive Behavior aspect of motivation refers to the strategy attached to a task (Martin, 2005). By having high Sense of Embodiment, an individual is more likely to make use of his physical body to complete the task. Research by Castonguay, Pila, Wrosch, and Sabiston (2014) supports this showing that there is a relationship between bodily self-awareness and motivation of physical activities. The sense of embodiment as the unifying component of soul and body can channel the energy required in the creation of dance choreography.

In addition to the three components mentioned, Ambrosio (2010) stated that in the creation of dance choreography, cognitive skill is critical in the dance movement. In choreography, the adjustment among dance components needs a cognitive process, which is Integrative Thinking. In dancing activities, some parts of the human brain, especially visual and auditory receptions turn to be active. Visual learning process appears when a dancer visualizes a concept or a movement in his mind while the auditory process happens when he synchronizes a movement with a certain music or rhythm (Kramarova \& Youmans, 2012). Some tensions can occur in this cognitive stage when a dancer experiences a mental bottleneck in figuring out the next series of a movement or being trapped in an under-pressure situation to synchronize a movement to a certain musical rhythm. The higher her Integrative Thinking, the more likely she can understand the complexities and find a solution to the problem (Martin \& Austen, 1999). Finding a suitable choreography is considered to be the solution to a problem. The Choice Cascade Model by Martin and Austen (1999) revealed that Integrative Thinking starts with identifying the unique characteristics, finding a causal relationship, sequencing, and achieving a resolution. Beginning with the stage of unique characteristics, a dancer will identify the main features of appropriate movements. In the next stage of the causal relationship, a dancer synchronizes her movements with other dance components, such as music and a plot of the story. The next sequencing stage is where a dancer establishes the appropriate sequence by considering the two previous stages. The last stage is a resolution where the solution is finally made, which is the final choreography, along with the possibility of emerging hindrances and problems. There is a positive correlation between "deeper" cognitive process and intrinsic orientation/ motivation (Garcia \& Pintrich, 1992).
In this study, the author aimed to examine variables which could predict motivational dimensions of a dancer in creating dance choreography. To date, there has been some research that investigates some classic and relevant variables only in dance motivation (Alter, 1997; Nieminen, 1998; Nieminen, Varstala, \& Manninen, 2001; Stinson, BlumenfieldJones, \& van Dyke, 1990). However, most of the researches discuss the issue using a descriptive and qualitative approach only, and there is no research focuses on motivation in creating dance choreography. Therefore, in this study, the authors focused on "The roles of sense of embodiment, integrative thinking, two kinds of time perspectives, object and spatial imagery in predicting the four motivational dimensions in creating dance choreography among the Hip-hop dancers in Jakarta, the capital city of Indonesia."

\section{Method}

\section{Participants and Design}

This study used a quantitative approach with a predictive correlational design to predict one continuous dependent variable based on several independent variables serving as the predictors. Statistical data analysis was a multiple linear regression applied four times to each dimension of motivation (Adaptive Cognition, Adaptive Behavior, Maladaptive Cognition, and Maladaptive Behavior).

Participants were 34 female Hip-hop dancers and 31 male Hip-hop dancers $\left(n=65, M_{\text {age }}=21.08\right.$ years old, $S D_{\text {age }}=1.674$ years) participating in this study. A questionnaire consisting psychological scales were distributed to participants. The sampling method used in this present study was the non-random/non-probability approach, in this case, convenience sampling based on the voluntarism of the prospective participants that can be accessed by the author (e.g. Teddlie \& Yu, 2007), with the following criteria: (a) a male or female in the early adulthood with the age range from 20 to 30 years old, (b) working as a Hip-hop choreographer; or having an experience as a Hip-hop dancer for at least two years, (c) having an experience of creating performed dance choreography, (d) residing in Jakarta, the capital city of Indonesia.

\section{Materials and Procedures}

The measure used for assessing motivation in creating dance choreography was adapted from the 
Motivation and Engagement Scale (MES; Martin, 2012). There are two ways of measurement in this regard: (a) first, the higher integrative level, which consists of Adaptive Cognition and Adaptive Behavior, as well as Maladaptive Cognition and Maladaptive Behavior, and (b) second, the lower operational level, which consists of eleven factors out of the four factors in the higher level (Martin, 2008a).

The fit index of the higher-order model of this motivation was obtained from the Confirmatory Factor Analysis (CFA) showed the RMSEA value of 0.045 (Martin, 2008a). The fit index of RMSEA value of

\section{Table 1}

Item and Scale Reliability Indexes of the Measurement Instrument $(n=30)$

\begin{tabular}{|c|c|c|c|c|}
\hline $\begin{array}{l}\text { Inventory (all in } \\
\text { Indonesian } \\
\text { language) }\end{array}$ & Example of item & $\begin{array}{l}N \text { of item } \\
\text { (Pre-test \& } \\
\text { Post-test) }\end{array}$ & $\alpha$ & $\begin{array}{c}\text { Corrected } \\
\text { Item-Total } \\
\text { Correlations }\end{array}$ \\
\hline $\begin{array}{l}\text { Adaptive/booster } \\
\text { behavior dimension } \\
\text { of MES }\end{array}$ & $\begin{array}{l}\text { "If I can't compose dance movement at first, I keep going over it until I do" } \\
\text { (Persistence); } \\
\text { "Before I start choreographing a dance, I plan out how I am going to do it." } \\
\text { (Planning); } \\
\text { "When I choreograph dance, I usually do it in places where I can concentrate" } \\
\text { (Task management) }\end{array}$ & $\begin{array}{l}\text { Pre: } 12 \\
\text { Post: } 12\end{array}$ & .852 & $.309-.674$ \\
\hline $\begin{array}{l}\text { Maladaptive } \\
\text { behavior/muffler } \\
\text { dimension of MES }\end{array}$ & $\begin{array}{l}\text { "I sometimes don't choreograph very hard before dance performance, so I have an } \\
\text { excuse if I don't do so well" } \\
\text { (Self-handicapping/sabotage); "I've pretty much given up being interested in } \\
\text { dance choreography“(Disengagement) }\end{array}$ & $\begin{array}{l}\text { Pre: } 8 \\
\text { Post: } 8\end{array}$ & .833 & $.280-.778$ \\
\hline $\begin{array}{l}\text { Adaptive/booster } \\
\text { cognition dimension } \\
\text { of MES }\end{array}$ & $\begin{array}{l}\text { "Dance choreography is important" (Value); "I feel very pleased with myself when } \\
\text { I really choreographing a very good dance" (Mastery/Learning focus); "If I try } \\
\text { hard, I believe I can do dance choreography well" (Self-efficacy/self-belief) }\end{array}$ & $\begin{array}{l}\text { Pre: } 12 \\
\text { Post: } 12\end{array}$ & .902 & $.238-.725$ \\
\hline $\begin{array}{l}\text { Maladaptive } \\
\text { cognition/Impeding } \\
\text { cognitive-affective/ } \\
\text { guzzler dimension of } \\
\text { MES }\end{array}$ & $\begin{array}{l}\text { "When dance performance show using my choreography are coming up, I worry a } \\
\text { lot" (Anxiety); "Often the main reason I choreograph a dance is because I don't } \\
\text { want to disappoint others (e.g. the community/family/partner)" (Failure } \\
\text { avoidance); "I'm often unsure how I can avoid doing poorly in choreographing a } \\
\text { dance" (Uncertain control) }\end{array}$ & $\begin{array}{l}\text { Pre: } 12 \\
\text { Post: } 11\end{array}$ & .871 & $.438-.845$ \\
\hline $\begin{array}{l}\text { Sense of } \\
\text { embodiment }\end{array}$ & $\begin{array}{l}\text { "I could no longer feel my body; it was almost as if it had disappeared" } \\
\text { (unfavorable item, reversely scored); "I experienced that I was located at some } \\
\text { distance behind the visual image of myself, almost as if I was looking at someone } \\
\text { else" (Self-locality); "The image was obeying my will, and I can make it move just } \\
\text { like I want it", "I felt as if I could cause movements of the image" (Sensation of } \\
\text { agency); "The image began to resemble my own (real) self, in terms of shape, skin } \\
\text { tone, textures or some other visual feature." (Sensation of body ownership) }\end{array}$ & $\begin{array}{l}\text { Pre: } 27 \\
\text { Post: } 27\end{array}$ & .936 & $.392-.773$ \\
\hline Integrative thinking & $\begin{array}{l}\text { "I consider various things to help me solve a problem"; "I understand the } \\
\text { relationships between the parts of the problem that I have encountered"; "I'm not } \\
\text { easily distracted or fooled by the complexity of my problems"; "I think of all the } \\
\text { possibilities that could happen from my steps" }\end{array}$ & $\begin{array}{l}\text { Pre: } 12 \\
\text { Post: } 3\end{array}$ & .859 & $.272-.772$ \\
\hline Object imagery & $\begin{array}{l}\text { "I can easily imagine and mentally rotate 3-dimensional geometric figures"; "My } \\
\text { images are very vivid and photographic"; "My mental images of different objects } \\
\text { very much resemble the size, shape and colour of actual objects that I have seen" }\end{array}$ & $\begin{array}{l}\text { Pre: } 15 \\
\text { Post: } 15\end{array}$ & .898 & $.261-.774$ \\
\hline Spatial imagery & $\begin{array}{l}\text { "My images are more like schematic representations of things and events rather } \\
\text { than detailed pictures"; "My images are more schematic than colourful and } \\
\text { pictorial"; "In high school, I had less difficulty with geometry than with art" }\end{array}$ & $\begin{array}{l}\text { Pre: } 15 \\
\text { Post: } 12\end{array}$ & .771 & $.278-.566$ \\
\hline $\begin{array}{l}\text { Present hedonistic } \\
\text { time perspective }\end{array}$ & $\begin{array}{l}\text { "Taking risks keeps my life from becoming boring", "It is important to put } \\
\text { excitement in my life", "I try to live my life as fully as possible, one day at a time" }\end{array}$ & $\begin{array}{l}\text { Pre: } 15 \\
\text { Post: } 9\end{array}$ & .821 & $.254-.725$ \\
\hline $\begin{array}{l}\text { Future time } \\
\text { perspective }\end{array}$ & $\begin{array}{l}\text { "When I want to achieve something, I set goals and consider specific means for } \\
\text { reaching those goals"; "I am able to resist temptations when I know that there is } \\
\text { work to be done" }\end{array}$ & $\begin{array}{l}\text { Pre: } 13 \\
\text { Post: } 9\end{array}$ & .829 & $.364-.682$ \\
\hline
\end{tabular}


0.06 or less indicates that the model could be accepted (Hooper, Coughlan, \& Mullen, 2008). Martin provided the information regarding the instrument with a sample of high school male students. The MES is not only used in an academic setting, but also in non-academic settings such as in music domain (Martin, 2008b)-a domain that is very close to the domain of artistic studies, similar to dance choreography in this present study. In his research, Martin (2008b) found that MES was valid and reliable to measure motivation and engagement in 224 young classical musicians, with an index of construct validity in the form of RMSEA of .06. Furthermore, the MES has been used in Edgar's study (2015) with Australian university students (MES -UC; 78 males, 152 females, three were unidentified) with $M_{\text {age }}=21.2$ years old and $S D_{\text {age }}=3.6$ years. The results showed that this instrument is applicable to measure their motivation and engagement. In addition, MES-UC used for a study in a study with 863 Chinese university students showed internal consistency reliability indexes ranging from $\alpha=.76$ to $\alpha=.82$ for the eleven sub-dimensions of motivation (Xueyan, 2013). Considering that MES can be used with young adults in non-academic domains (such as art), this present study used the measure to assess motivation of dance choreographers. This study also investigated the reliability of these instruments as shown in Table 1. The adaptation process is done acknowledged by Andre J. Martin via email correspondence between Vivi Angelina (the first author) and him (A. J. Martin, personal com- munication, December 14, 2015). Response options used in this scale ranged from Strongly Disagree (scoring 1) to Strongly Agree (scoring 6).

The measurement for Sense of embodiment was based on Kilteni et al.'s model (2012), which is built on three inherent components; the sensation of self-locality (feeling that the self is in the biological body), the sensation of agency (the feeling of having complete control of the body), and sensation of body ownership (the feeling of having power over all the processes that occur in the body). Kilteni et al. (2012) argued that the three measuring instruments can be used to generate a composite score of sense of embodiment because it is able to represent the perception of oneness between the biological body and selfidentity, the ability to experience a variety of sensations that move toward the body, the capability to simulate the body existence in the mind, manipulating it mentally/psychologically, and designing a change in a spatial environment, as well as asserting its presence and selecting its actions. The sensation of the self-locality was measured using the Out of Body Experience Questionnaire by Ehrsson (2007), the sensation of agency measurement was modified and adapted from the measure developed by Kalckert and Ehrsson (2014), and the sensation of body ownership was measured using the instrument developed by Botvinick and Cohen (1998). The instruction in the scale was as follows, "In this section, you are asked to envision yourself dancing. Remember well what you

Table 2

Psychodemographic Characteristics of Participants $(n=65)$

\begin{tabular}{ccr}
\hline Characteristic & $n$ & $\%$ \\
\hline Length of experience in dancing & 6 & \\
2-3 years & 29 & 44.62 \\
3-5 years & 6 & 9.23 \\
5-7 years & 24 & 36.92 \\
> 7 years &
\end{tabular}

Lengths of experience in creating dance choreography

$\begin{array}{lcr}2-3 \text { years } & 46 & 70.77 \\ 3-5 \text { years } & 12 & 18.46 \\ 5-7 \text { years } & 3 & 4.62 \\ >7 \text { years } & 4 & 6.15\end{array}$

Consideration of creating dance choreography

$\begin{array}{lll}\text { The first choice } & 31 & 47.69\end{array}$

$\begin{array}{lll}\text { Preferred than other physical activities } & 20 \quad 30.77\end{array}$

Less preferred than other physical activities $\quad 11 \quad 16.92$

\begin{tabular}{lll} 
The last choice & 3 & 4.62 \\
\hline
\end{tabular} 
'see' in your mind. Note: The word 'image' in this questionnaire means visualization that appears in your mind when you imagine something." Response options used in this scale ranged from Strongly Disagree (scoring 1) to Strongly Agree (scoring 6).

The measure off Integrative Thinking was developed from the Choice Cascade Model by Martin and Austen (1999). The measurement of Object-Spatial Imagery was adapted from the instrument of Blajenkova et al. (2006), the Object-Spatial Imagery Questionnaire (OSIQ) that refers to the preference and visual imagination experience. The measurement for Time Perspective was based on the Zimbardo Time Perspective Inventory (ZTPI) by Zimbardo and Boyd (1999).

All of the measures used had good reliability indexes as shown in the result of a pilot study with 30 participants (Cronbach's Alpha > 600 and Corrected Item-Total Correlation > .250; see Table 1).

\section{Results}

Psychodemographic characteristics of the participants in this study are presented in Table 2.

Assumption tests of multiple linear regressions of this study were all met. Data were normally distributed (in the normal p-p plot, the points in the standardized residuals gathered were scattered around the normal trend line; e.g. Figure 1 for criterion variable Adaptive Cognition). One-Sample Kolmogorov-Smirnov test confirmed that the data are normally distributed $\left(p_{\text {Adaptive Cognition }}=.455 ; p_{\text {Adaptive Behavior }}=.475 ; p_{\text {Maladaptive }}\right.$ Cognition $=.529 ; p_{\text {Maladaptive Behavior }}=.781$; all $\left.p>.05\right)$. There was no multicollinearity among the predictor variables (Tolerance values of all predictors were more than .1 and VIF value of all predictors were less than
Table 3

Results of Multicollinearity Test

\begin{tabular}{lcc}
\hline \multicolumn{1}{c}{ Predictor Variable } & Tolerance & VIF \\
\hline Sense of embodiment & .653 & 1.531 \\
Integrative thinking & .581 & 1.720 \\
Object imagery & .683 & 1.465 \\
Spatial imagery & .671 & 1.491 \\
Time perspective: Present & .851 & 1.175 \\
hedonistic & .691 & 1.446 \\
Time perspective: Future & .
\end{tabular}

10; e.g. Table 3 for criterion variable Maladaptive Cognition), and the heteroscedasticity was absent (the scatterplot does not show a specific pattern, and the points are scattered above and below the number 0 ; e.g. Figure 1 for criterion variable Maladaptive Behavior).

The sense of embodiment together with Integrative Thinking, Object Imagery, Spatial Imagery, Time Perspective of Future and Time Perspective of Present Hedonistic simultaneously predicts the Adaptive Behavior by $48.5 \% ; F(6,64)=9.111, p=.000, R^{2}=$ .485. However, in terms of main effects, the Adaptive Behavior is significantly predicted by the proposed predictor variables except for Integrative Thinking (see Table 4). The sense of embodiment (SE) positively predicts the Adaptive Behavior. The variable of Adaptive Behavior could not be predicted by the variable of Integrative Thinking (IT). Object Imagery (OI) positively predicts the Adaptive Behavior. Spatial Imagery (SI) negatively predicts the Adaptive Behavior. Time Perspective of Present Hedonistic (PH) positively predicts the Adaptive Behavior. Time Perspective of Future (F) positively predicts Adaptive

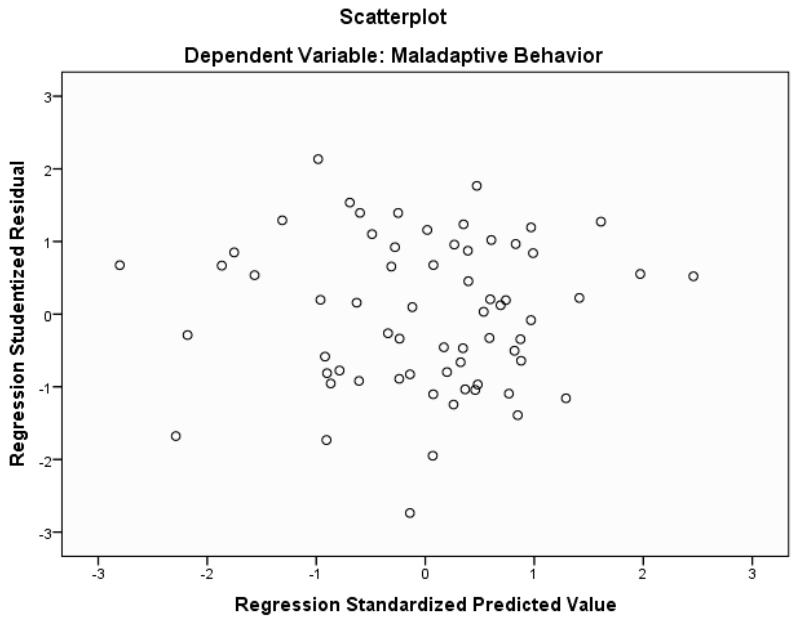

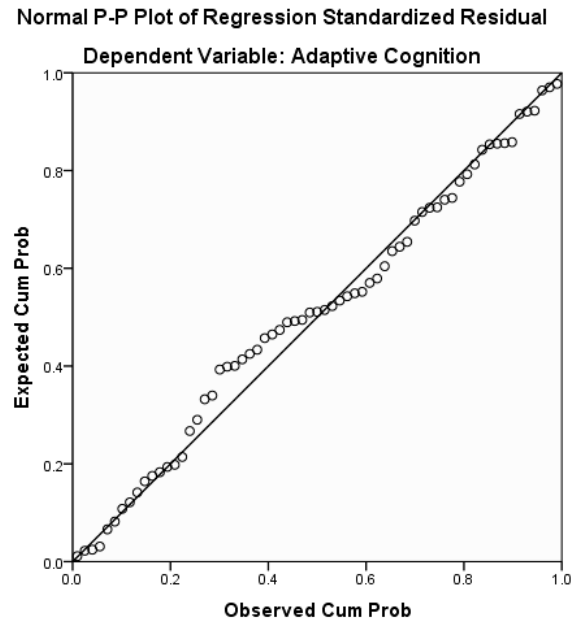

Figure 1. Normality of residuals test (left) and heteroscedasticity test (right). 
Behavior.

The sense of embodiment together with Integrative Thinking, Object Imagery, Spatial Imagery, Time Perspective of Future and Time Perspective of Present Hedonistic could simultaneously predict the Adaptive Cognition by $27.6 \%\left(F(6,64)=3.687, p=.004, R^{2}=\right.$ .276). However, in terms of main effects, the Adaptive Cognition could only be predicted significantly by Spatial Imagery and Object Imagery (see Table 4).
Spatial Imagery (SI) negatively predicts the Adaptive Behavior and the Adaptive Cognition, whereas Object Imagery (OI) positively predicts the Adaptive Cognition.

The sense of embodiment together with Integrative Thinking, Object Imagery, Spatial Imagery, Time Perspective of Future, and Time Perspective of Present Hedonistic could simultaneously predict Maladaptive Behavior by $44.1 \%(F(6,64)=7.625, p$

Table 4

Multiple Linear Regression Analysis Predicting Dimensions of Motivation and Engagement of Hip-Hop Dance Choreographers $(n=65)$

\begin{tabular}{|c|c|c|c|c|}
\hline Model & $B$ & $S E B$ & $\bar{\beta}$ & $p$ \\
\hline \multicolumn{5}{|l|}{ Model 1: } \\
\hline \multicolumn{5}{|l|}{ Variables predicting Adaptive Behavior } \\
\hline Sense of embodiment & .148 & .061 & .284 & $.018^{*}$ \\
\hline Integrative thinking & .037 & .165 & .028 & .823 \\
\hline Object imagery & .353 & .128 & .315 & $.008^{* *}$ \\
\hline Spatial imagery & -.570 & .151 & -.436 & $.000^{*}$ \\
\hline Time perspective: Present hedonistic & .963 & 1.907 & .212 & $.042^{*}$ \\
\hline Time perspective: Future & .187 & 1.882 & .373 & $.002^{* *}$ \\
\hline \multicolumn{5}{|l|}{ Model 2: } \\
\hline \multicolumn{5}{|l|}{ Variables predicting Adaptive Cognition } \\
\hline Sense of embodiment & .036 & .066 & .076 & .585 \\
\hline Integrative thinking & .014 & .179 & .012 & .936 \\
\hline Object imagery & .324 & .138 & .317 & $.023^{*}$ \\
\hline Spatial imagery & -.485 & .163 & -.407 & $.004^{* *}$ \\
\hline Time perspective: Present hedonistic & 1.368 & 2.060 & .080 & .509 \\
\hline Time perspective: Future & 4.016 & 2.033 & .265 & .053 \\
\hline \multicolumn{5}{|l|}{ Model 3: } \\
\hline \multicolumn{5}{|c|}{ Variables predicting Maladaptive Behavior } \\
\hline Sense of embodiment & .056 & .066 & .103 & .400 \\
\hline Integrative thinking & -.340 & .179 & -.245 & .062 \\
\hline Object imagery & -.361 & .138 & -.311 & $.011^{*}$ \\
\hline Spatial imagery & .523 & .163 & .386 & $.002^{* *}$ \\
\hline Time perspective: Present hedonistic & 8.698 & 2.060 & .449 & $.000^{* *}$ \\
\hline Time perspective: Future & 1.735 & 2.032 & .101 & .397 \\
\hline \multicolumn{5}{|l|}{ Model 4: } \\
\hline \multicolumn{5}{|c|}{ Variables predicting Maladaptive Cognition } \\
\hline Sense of embodiment & .045 & .051 & .115 & .383 \\
\hline Integrative thinking & -.347 & .140 & -.343 & $.016^{*}$ \\
\hline Object imagery & -.113 & .108 & -.134 & .299 \\
\hline Spatial imagery & .213 & .127 & .216 & .099 \\
\hline Time perspective: Present hedonistic & 6.533 & 1.610 & .463 & $.000^{* *}$ \\
\hline Time perspective: Future & 3.196 & 1.589 & .255 & $.049^{*}$ \\
\hline
\end{tabular}


$\left.=.000, R^{2}=.441\right)$. However, in terms of main effects, the Maladaptive Behavior could only be predicted significantly by Object Imagery, Spatial Imagery, and Time Perspective of Present Hedonistic (see Table 4). Object Imagery negatively predicts the Maladaptive Behavior. Spatial Imagery as a contrasting imagery preference from Object Imagery also predicts the Maladaptive Behavior but in a positive way. Time Perspective of Present Hedonistic could significantly predict Maladaptive Behavior positively.

The sense of embodiment together with Integrative Thinking, Object Imagery, Spatial Imagery, Time Perspective of Future, and Time Perspective of Present Hedonistic could simultaneously predict Maladaptive Cognition by $35.7 \%\left(F(6,64)=5.365, p=.000, R^{2}=\right.$ .357). However, in terms of main effects, Maladaptive Cognition was only predicted significantly by Integrative Thinking, Spatial Imagery, and Time Perspective of Present Hedonistic (see Table 4). Integrative Thinking could significantly predict Maladaptive Cognition negatively. Time perspective of Future predicted Maladaptive Cognition.

\section{Discussion}

The sense of embodiment (SE) positively predicts the Adaptive Behavior. Kilteni et al. (2012) stated that an individual with higher SE tends to enhance his sensation over himself and his body. A choreographer might "“feel' the art object or event as directly related to her/his own body" (Candidi, Aglioti, \& Haggard, 2012, p. 116). Meanwhile, Adaptive Behavior is a motivation development strategy regarding planning, task management, and persistence (Martin, 2010). With higher SE ability, the dancer is able to know her body and herself better allowing herself to plan and develop a dance choreography, which involved her body. This is in line with the results of study by Castonguay et al. (2014) that finds the correlation between a person's selfawareness of his body and his motivation in physical activities. SE as an element unifying soul and body is able to direct the energies channeled into the creation of creative thing as one of the constituent elements in dance choreography. However, SE cannot predict other dimensions of motivation of choreographing. In a viewpoint, SE is indeed disconnected or separated from the aesthetic cognitive process, and this phenomenon is called "disembodiment" (Northoff, 2008), although this view has not been supported by recent researches in neuro-psychology. If we follow this view, in certain phases, the body is assumed by a choreographer as a purely physiological body independent from the cognitive and behavioral processes. The body does not draw up the choreographer's perception building motivation to creating dance, but the body is positioned as merely as an objective tool of cognitive desires.

Adaptive Behavior, Maladaptive Behavior, and Adaptive Cognition could not be predicted by Integrative Thinking (IT). However, Maladaptive Cognition could be predicted by it. IT is a type of thinking meant to find a solution to a complex problem (Martin \& Austen, 1999). Here, IT served as the buttress or mitigating means against the occurrence of Maladaptive Cognition. Showers (1992) also stated that IT is a coping technique with the negative thought making its impact is less severe. In addition, based on the Choice Cascade model, Martin and Austen (1999) stated that an integrative thinker works in a dynamic and repetitive way by advancing stability and clarity, and thus, avoiding a long status quo. IT does not automatically seek for a long-term solution to a problem, hence it does not significantly play a role in shaping the persistence and learning focus of Adaptive Behavior and Cognition dimension of motivation, but it functions more by balancing the situations and finding an appropriate solution to achieve the expected steadiness. The anticipated risk is that the integrative thinking is vigorous, context-dependent, always moves back and forth, from the pros/positives to cons/negatives and vice versa, therefore it looks changeful, unstable, thus not useful for explaining adaptive behavior. To strengthen this proposition, we can tune the expression Heath (1968), "Persons whose thought processes are more integrative and organized, not infused by what psychoanalysts call the primary process or dreamlike images, are more mature" ( $p$. 11). Paradoxically, O'Toole (as cited in Barrett, 2011) stated that the originality and novelty of art require dreamlike images (with the different nature compared with integrative thinking) that are free from sociocultural pressures that usually promote rigidity and formalism-rationality. Not surprisingly, this present study found no direct predictive relationship between IT and (Mal-)adaptive Behavior in the context of artistic dance choreography. However, the finding that Integrative Thinking negatively predicts Maladaptive Cognition is in line with the statement of Martin and Austen (1999) that stated that an individual with a high skill of Integrative Thinking could deal with complexities, tolerate the uncertainties, and manage tensions in finding the creative 
solution to a problem. An integrative thinker sees the challenge as a tension to be more creative and develops himself to manage the problem better (Martin \& Austen, 1999). Therefore, a dancer with a higher integrative thinking was more likely to avoid Maladaptive Cognition, which included worries, failure avoidance, and self-control inability.

Object Imagery (OI) positively predicts the Adaptive Behavior and Adaptive Cognition. A person with OI preference is more likely to be successful in his performance in the area of creative production (Kunzendorf, as cited in Blajenkova et al., 2006) and tasks of visual art (Rosenberg, as cited in Blajenkova et al., 2006). In the area of creative production, OI helps in the movement creation of the dancer's body to be beautifully performed. In line with the finding, Object Imagery could also negatively predict Maladaptive Behavior such that self-sabotage and negative disengagement. The ability to develop self-sabotages and disengagement feeling seems to be generated by the thoughts against relations among objects in a space. The finding that Object Imagery negatively predicts the Maladaptive Behavior showed that a choreographer with a low level of Object Imagery tended to develop the Maladaptive Behavior in the creation of dance choreography, at least in the context of this study.

Spatial Imagery as the counterpart of imagery preference of Object Imagery also predicts the Maladaptive Behavior but in a positive way. In line with the finding, Spatial Imagery (SI) negatively predicts the Adaptive Behavior and Adaptive Cognition. Results of this present study confirm that the Spatial Imagery can predict the aspects of adaptive behavior negatively and aspects of maladaptive behavior positively. Indeed, an artist in the area of creative production (such as Hip-hop choreographers in this present study) are more likely to have a preference of Objects Imagery, and, on the contrary, technicians and scientists more likely to have a preference for Spatial Imagery (Blajenkova et al., 2006; Kozhevnikov, Kosslyn, and Shephard, 2005). Another explanation, Jansen and Richter (2015) stated that spatial imagery of experienced dancers is better than novice dancer; meanwhile, of participants in this study were dominated by the dancer-choreographer whose dancing experience is less than five years $(53.85 \%$, see Table 2).

Time Perspective of Present Hedonistic (PH) positively predicts the Adaptive Behavior. An individual with Time Perspective of PH tends to have low control towards ego and impulses, leading to risky and novelty as well as sensation seeking behavior (King, 2015; Zimbardo \& Boyd, 1999). Meanwhile, Lepecki (2016) stated that although the choreography is a production and reproduction of dance that requires disciplinimg body of the dancer, and somehow exerting power of the choreographer, or can be seen as a "contract" between the planning and realization of the movement, it also does not that "dry". Dance choreography provides negotiative spaces for the risky uncertainty aspect of dancing, which gives a probability of the free creation of meaning that fits in well with the spirit of present hedonistic time perspective. Therefore it is called "choreography" and not "choreopolice" (Lepecki, 2016, p. 17). However, Time Perspective of Present Hedonistic also positively predicts Maladaptive Cognition and Maladaptive Behavior. In addition to the above explanations, Zimbardo and Boyd (1999) stated that a person with high time perspective of Present Hedonistic is also associated with a lack of focus on future consequences, a low preference against consistency and self-regulation. The low preference for consistency may distract the focus on the expected goal, which was the creation of dance choreography. The maladaptive cognition and behavior are shown by the dancers through their actions that hindered their own goal and attitude to give up (Martin, 2010).

Time Perspective of Future (F) positively predicts Adaptive Behavior. Zimbardo and Boyd (1999) stated that a person with a high time perspective of $\mathrm{F}$ is very concerned with future consequences, has a prudent approach to matters, and develops high preference over consistency. The finding of this prediction is in line with the explanation that Adaptive Behavior is an individual's strategy to attach himself to a task until the expected goal is achieved (Martin, 2010). However, this present study also found that Time Perspective of Future positively predicts Maladaptive Cognition. A dancer with time perspective of Future has obvious concerns over consequences of his actions, his focus of responsibility, advancement of his duties, and focus on generating results (Zimbardo \& Boyd, 1999). This could lead a dance choreographer to experience worries for not achieving her goal, as shown from her anxieties, attitude to avoid failure, etc. Those two ways of effects of the Future time perspective (i.e. positive and negative) were well described by Holman and Silver (2005), "focusing on future goals can help us to adapt life's main changes, but having fears about an ambiguous future may also ... render us vulnerable to the negative impact of chronic stress" (p. 407). 


\section{Limitations and Future Directions}

By covering four theoretical models in the analysis, the readability of the exposition of the process and results of this study might be less secured. In addition, there are many paradoxes that should be observed. On the one hand this might require a peculiar effort from the readers and users of this present study to select and sort the article components to be understood and used in accordance with their needs. On the other hand, the paradoxes that exist in the context of psychology of art research might provide an insight enriching the theoretical knowledge and phenomenological experiences. Future researchers are still advised to review the measurement instruments used in this study, particularly the sense of embodiment scale that seems to require further refinement to be used in the artistic world, as well as to incorporate a qualitative method to gather deeper understanding on the motivation dynamics in it's the social context.

As for the practical implications, the measure assessing preference for Object and Spatial Imagery can be used to predict the motivation tendency of choreographers. Object imagery was found to have a more direct positive energizer for dancers compared to Spatial Imagery. Someone with a preference for Object Imagery is predicted to be more successful in the field of creative production, one of them in creating dance choreography. Interventions need to be designed so that the dancer can balance his/her time perspectives particularly between Present Hedonistic and Future perspectives. Development of Future time perspective to increase the Adaptive Behavior of dancers is pivotal to support the implementation of activities that encourage a creation of dance choreography settlement activity. The Sense of Embodiment and Integrative Thinking capabilities are valuable in helping dancers in a choreography creation process.

\section{Conclusions}

Taken together, the findings showed that the imageries are the most salient variable in predicting the motivational dimensions for Hip-hop dance choreography. The adaptive dimensions can not be predicted by Integrative Thinking. The maladaptive dimensions are clearly predicted by time perspective variable of present hedonistic. Meanwhile, the influence of Object and Spatial Imagery showed opposing results.

\section{References}

Alter, J. B. (1997). Why dance students pursue dance: Studies of dance students from 1953 to 1993. Dance Research Journal, 29(2), 70-89. http://dx. doi.org/10.2307/1478735

Ambrosio, N. (2010). Learning about dance: Dance as an art form and entertainment (6th ed.). Dubuque, Iowa: Kendall-Hunt Publishing.

Ashley, L. (2002). Essential guide to dance. London: Hodder \& Stoughton.

Barrett, E. (2011). Kristeva reframed: Interpreting key thinkers for the arts. London: I. B. Tauris.

Blajenkova, O., Kozhevnikov, M., \& Motes, M. A. (2006). Object-spatial imagery: A new self-report imagery questionnaire. Applied Cognitive Psychology, 20(2), 239-263. http://dx.doi.org/10.1002/acp.1182

Botvinick, M., \& Cohen, J. (1998). Rubber hands 'feel' touch that eyes see. Nature, 391(6669), 756. http:// dx.doi.org/10.1038/35784

Brouwer, M. A. W. (1992). Badan manusia dalam cahaya psikologi fenomenologis. Jakarta, Indonesia: Gramedia.

Candidi, M., Aglioti, S. M., \& Haggard, P. (2012). Embodying bodies and worlds. Review of Philosophy and Psychology, 3(1), 109-123. http://dx.doi.org /10.1007/s13164-012-0091-6

Castonguay, A. L., Pila, E., Wrosch, C., \& Sabiston, C. M. (2014). Body-related self-conscious emotions relate to physical activity motivation and behavior in men. American Journal of Men's Health, 9(3), 209-221. http://dx.doi.org/10.1177/1557988314537517

Collins, A., Judge, G., \& Rickman, N. (2005). Thinking economically about plagiarism. Proceedings of the 39th Annual Meeting of the Canadian Economics Association, McMaster University, Hamilton, May 2005. Retrieved from http://economics.ca/2005/ papers/0308.pdf

Edgar, S. (2015). Identifying the influence of gender on motivation and engagement levels in student physiotherapists. Medical Teacher, 37(4), 348-353. http://dx.doi.org/10.3109/0142159x.2014.948829

Ehrsson, H. H. (2007). The experimental induction of out-of-body experiences. Science, 317(5841), 1048 [supporting online material]. Retrieved from http:// www.neuro.ki.se/ehrsson/pdfs/Ehrsson-Science2007-with-SOM.pdf

Forgeard, M. J. C., \& Mecklenburg, A. C. (2013). The two dimensions of motivation and a reciprocal model of the creative process. Review of General 
Psychology, 17(3), 255-266. http://dx.doi.org/10. 1037/a0032104

Franklin, E. (2012). Dynamic alignment through imagery (2nd ed.). Champaign, IL: Human Kinetics.

Garcia, T., \& Pintrich, P. R. (1992). Critical thinking and its relationship to motivation, learning strategies, and classroom experience. Paper presented at the 100th Annual Meeting of the American Psychological Association, Washington, DC, August 14-18. Retrieved from http://files.eric.ed.gov/fulltext/ED35 1643.pdf

Hawkins, A. M. (1991). Moving from within: A new method for dance making. Chicago, IL: Cappella Books.

Hayes, J. R. (1989). Cognitive processes in creativity. In J. A. Glover, R. R. Ronning, \& C. R. Reynolds (Eds.), Handbook of creativity: Part of the series Perspectives on Individual Difference (pp. 135145). New York: Springer Science+Business Media. http://dx.doi.org/10.1007/978-1-4757-5356-1_7

Heath, D. H. (1968). Growing up in college: Liberal education and maturity. San Fransisco: JosseyBass, Inc. Retrieved from http://files.eric.ed.gov/ fulltext/ED029347.pdf

Holman, E. A., \& Silver, R. C. (2005). Futureoriented thinking and adjustment in a nationwide longitudinal study following the September 11th terrorist attacks. Motivation and Emotion, 29, 389-410. http://dx.doi.org/10.1007/s11031-006-9018-9

Holt, E. A., Fagerheim, B., \& Durham, S. (2014). Online plagiarism training falls short in biology classrooms. Cell Biology Education, 13(1), 8389. http://dx.doi.org/10.1187/cbe.13-08-0146

Hooper, D., Coughlan, J., \& Mullen, M. (2008). Structural equation modelling: Guidelines for determining model fit. The Electronic Journal of Business Research Methods, 6(1), 53-60. Retrieved from http://arrow.dit.ie/cgi/viewcontent.cgi?article $=1001 \&$ context $=$ buschmanart

Jansen, P., \& Richter, S. (2015). Effects of a onehour creative dance training on mental rotation performance in primary school aged children. International Journal of Learning, Teaching and Educational Research, 13(4), 49-57.

Kalckert, A., \& Ehrsson, H. H. (2014). The spatial distance rule in the moving and classical rubber hand illusions. Consciousness and Cognition, 30, 118132. http://dx.doi.org/10.1016/j.concog.2014.08.022

Kilteni, K., Groten, R., \& Slater, M. (2012). The sense of embodiment in virtual reality. Presence: Teleoperators and Virtual Environments, 21(4), 373-387. http://dx.doi.org/10.1162/pres_a_00124
King, R. B. (2015). Does your approach to time matter for your learning? The role of time perspectives on engagement and achievement. Educational Psychology, 36(7), 1261-1281. http://dx.doi.org/10. 1080/01443410.2015.1045835

Koreografer Rumingkang plagiat karya tari. (2010). Pikiran Rakyat. Retrieved from http://www.pikiranrakyat.com/bandung-raya/2010/07/16/117846/ koreografer-rumingkang-plagiat-karya-tari

Kozhevnikov, M., Kosslyn, S., \& Shephard, J. (2005). Spatial versus object visualizers: A new characterization of visual cognitive style. Memory \& Cognition, 33(4), 710-726. http://dx.doi.org/10.3758/bf03195337

Kramarova, O., \& Youmans, R. J. (2012). Cognition and kinesiology: A dual-strategy approach to remembering choreography. Proceedings of The Human Factors and Ergonomics Society Annual Meeting, 56(1), 2457-2461. http://dx.doi.org/10.11 77/1071181312561500

Lepecki, A. (2016). Singularities: Dance in the age of performance. New York, NY: Routledge.

Liem, G. A. D., \& Martin, A. J. (2012). The Motivation and Engagement Scale: Theoretical framework, psychometric properties, and applied yields. Australian Psychologist, 47, 3-13. http://dx.doi.org/ 10.1111/j.1742-9544.2011.00049.x

Martin, A. J. (2005). Exploring the effects of a youth enrichment program on academic motivation and engagement. Social Psychology of Education, 8, 179-206.http://dx.doi.org/10.1007/s11218-004-6487-0

Martin, A. J. (2007). Examining a multidimensional model of student motivation and engagement using a construct validation approach. British Journal of Educational Psychology, 77(2), 413-440. http://dx. doi. org/10.1348/000709906X118036

Martin, A. J. (2008a). Enhancing student motivation and engagement: The effects of a multidimensional intervention. Contemporary Educational Psychology, 33(2), 239-269. http://dx.doi.org/10.1016/j.cedpsych. 2006.11.003

Martin, A. J. (2008b). Motivation and engagement in music and sport: Testing a multidimensional framework in diverse performance settings. Journal of Personality, 76(1), 135-170. http://dx.doi.org/10.1111/ j.1467-6494.2007.00482.x

Martin, A. J. (2010). Multidimensional motivation and engagement: The Motivation and Engagement Wheel - 'Extension study' section. In D. McInerney \& V. McInemey, Educational psychology: Constructing learning (5th ed.) (pp. 238-241). Sydney: Pearson.

Martin, A. J. (2012). The Motivation and Engagement Scale (12th ed.). Sydney, Australia: Lifelong Achi- 
evement Group.

Martin, R., \& Austen, H. (1999, Fall). The art of integrative thinking. Rotman Management, 2-5. Retrieved from https://rogerlmartin.com/docs/default -source/Articles/integrative-thinking/the-art-ofintegrative-thinking

Masic, I. (2014). Plagiarism in scientific research and publications and how to prevent it. Materia Socio Medica, 26(2), 141-146. http://dx.doi.org/10.5455/ msm.2014.26.141-146

Nagabhushan, P. (2012). Academic motivation and engagement: An examination of its factor structure in senior school years. The European Journal of Social \& Behavioural Sciences, 2(2), 260-277. http://dx.doi.org/10.15405/futureacademy/ejsbs(230 1-2218).2012.2.11

Nieminen, P. (1998). Participation motives in relation to background and involvement variables among Finnish non-professional dancers. Dance Research Journal, 30(2), 53-70. http://dx.doi.org/10.2307/14 78838

Nieminen, P., Varstala, V., \& Manninen, M. (2001). Goal orientation and perceived purposes of dance among Finnish dance students: A pilot study. Research in Dance Education, 2(2), 175-193. http:// dx.doi.org/10.1080/14647890120100791

Northoff, G. (2008). Is appraisal 'embodied' and 'embedded'? A neurophilosophical investigation of emotions. Journal of Consciousness Studies, 15(5), 68-99.

Owens, E. (2015). I just can't get down with hip hop anymore. The Huffington Post. Retrieved 21 March 2016, from http://www.huffingtonpost.com/ernestowens/i-just-cant-get-down-with_b_7965368.html

Roberts, D. (2012). The evolution of hip-hop: Is it even hip-hop? El Iluminador. Retrieved 21 March 2016, from http://www.eliluminador.com/2012/03/ 07/evolution-of-hip-hop/

Setiawati, R. (2008). Seni tari untuk Sekolah Menengah Kejuruan Jilid 1. Jakarta: Direktorat Pembinaan
Sekolah Menengah Kejuruan, Direktorat Jenderal Manajemen Pendidikan Dasar dan Menengah, Departemen Pendidikan Nasional. Retrieved from http://ftp.unpad.ac.id/bse/10_SMK/kelas10_smk_se ni-tari_rahmida.pdf.pdf

Showers, C. (1992). Evaluatively integrative thinking about characteristics of the self. Personality and Social Psychology Bulletin, 18(6), 719-729. http://dx. doi.org/10.1177/0146167292186008

Stinson, S. W., Blumenfield-Jones, D., \& van Dyke, J. (1990). Voices of young women dance students: An interpretive study of meaning in dance. Dance Research Journal, 22(2), 13-22. http://dx.doi.org/ $10.2307 / 1477780$

Sutrisno, M. (2015). Estetika kehidupan (Bagian I). SINDOnews.com. Retrieved from http://www. koran-sindo.com/read/964552/149/estetikakehidupan-bagian-i-1423966124

Teddlie, C. \& Yu, F. (2007). Mixed methods sampling: A typology with examples. Journal of Mixed Methods Research, 1(1), 77-100. http://dx. doi.org/ 10.1177/2345678906292430

Weinberg, R. (2008). Does imagery work? Effects on performance and mental skills. Journal of Imagery Research in Sport and Physical Activity, 3(1), 1-21. http://dx.doi.org/10.2202/1932-0191.1025

Xueyan, L. (2013). Chinese university students' motivation and engagement: Their antecedents and outcomes (Unpublished doctoral dissertation). The University of Hong Kong, Hong Kong.

Yokochi, S. \& Okada, T. (2005). Creative cognitive process of art making: A field study of a traditional Chinese ink painter. Creativity Research Journal, 17(2-3), 241-255. http://dx.doi.org/10.1080/1040 0419.2005.9651482

Zimbardo, P. G., \& Boyd, J. N. (1999). Putting time in perspective: A valid, reliable individual-differences metric. Journal of Personality and Social Psychology, 77(6), 1271-1288. http://dx.doi.org/10.1037/0022 $-3514.77 .6 .1271$ 